\title{
POTENSI BISNIS USAHA PLAKAT DI DESA PASIR WETAN
}

\author{
Kenci Murtianingsih \\ UIN Prof. KH. Saifuddin Zuhri \\ kencimurtia.ningsih@gmail.com \\ Kenny Savitri \\ UIN Prof. KH. Saifuddin Zuhri \\ kencimurtia.ningsih@gmail.com \\ Nurhayun Fatmawati \\ UIN Prof. KH. Saifuddin Zuhri \\ kencimurtia.ningsih@gmail.com \\ Salmaa AliifahKultsum \\ UIN Prof. KH. Saifuddin Zuhri \\ kencimurtia.ningsih@gmail.com \\ Tania Dwi Oktaviani \\ UIN Prof. KH. Saifuddin Zuhri \\ kencimurtia.ningsih@gmail.com
}

\begin{abstract}
Abstrak- Plakat merupakan sebuah catatan yang dipasang di tempat umum, seperti kartu kecil, rambu atau plang. Plakat dapat dipajang ataupun digantung di kendaraan atau bangunan, rumah. Di Desa Pasir Wetan memiliki potensi home industri yang sudah lama berkembang yaitu kerajinan plakat yang terbuat dari besi, logam, kayu atau pun keramik. Hampir sebagian masyarakat diDesa Pasir Wetan bekerja dengan membuat kerajinan yang terbuat dari besi, logam, keramik dan masih banyak lagi. Di Desa Pasir Wetan memiliki potensi atau peluang yang besar untuk home industri kerajinan plakat.Salah satu home industri plakat yang berada di Desa Pasir Wetan yaitu Azka Jaya Trhophy didirikan pada tahun 2010 oleh Bapak Nanang Kunto Adi, bersama dengan 4-6 orang lainnya bekerja sama dalam pembuatan Industri Plakat. Di Azka Jaya Throphy menyediakan piala/throphy, plakat akrilik, plakat kayu, plakat fiber glass, pin, name tag, medali, samir wisuda dan berbagi kerajinan lain yang sejenis. Dari hal ini tentu terdapat potensi yang dapat dikembangkan kembali menjadi peluang bisnis home industri lainnya, atau mulai mengembangkan industri plakat lagi dengan mempromosikan hasil plakat di Desa Pasir Wetan. Karena industrialisasi adalah pembangunan ekonomi melalui transformasi sumber daya dan aktivitas energi yang digunakan sebagai upaya melipat gandakan produk, dan keberadaan adanya home industri di desa memiliki arti penting dalam kerangka pembangunan nasional.
\end{abstract}

Kata Kunci : Potensi, Plakat, Home Industri

Abstrack -plaque is a note posted in a public place, such as a small card, sign or sign. Plaques can be displayed or hung on vehicles or buildings, homes. The village 
of Pasir Wetan has the potential for a long-developing home industry, namely the craft of plaques made of iron, metal, wood or ceramics. Most of the people in Pasir Wetan Village work by making crafts made of iron, metal, ceramics and much more. In Pasir Wetan Village, there is great potential or opportunity for the home plaque craft industry. One of the home plaque industries located in Pasir Wetan Village, namely Azka Jaya Trophy was founded in 2010 by Mr. Nanang Kunto Adi, along with 4-6 other people working together in Manufacture of Plaque Industry. At Azka Jaya Trophy, we provide trophies, acrylic plaques, wooden plaques, fiber glass plaques, pins, name tags, medals, graduation samirs and other similar crafts. Of course, there is potential that can be developed into a home industry business opportunity. others, or start developing the placard industry again by promoting the placards in Pasir Wetan Village. Because industrialization is economic development through the transformation of energy resources and activities that are used as an effort to multiply products, and the existence of home industries in villages has an important meaning in the framework of national development.

Keywords : Potential, Plaque, Home Industry 


\section{PENDAHULUAN}

Desa Pasir Wetan yang berada di Kabupaten Banyumas, Jawa Tengah merupakan pengahsil logam terbanyak di daerah tersebut. Menjadikan sebagian

mata pencahariannya berkutik terkait perlogaman salah satunya yaitu home industri palakat. Salah satu industri plakat yang berada di Desa Pasir Wetan yang cukup terkenal adalah Azka Jaya Thropy. Azka Jaya Throphy didirikan pada tahun 2010 oleh Bapak Nanang Kunto Adi, bersama dengan 4-

6 orang lainnya bekerja sama dalam pembuatan Industri Plakat. Di Azka Jaya Throphy menyediakan piala/throphy, plakat akrilik, plakat kayu, plakat fiber glass, pin, name tag, medali, samir wisuda dan berbagi kerajinan lain yang sejenis. Dengan harga termurah berkisaran Rp 5000 untuk pin dan harga termahal berkisaran Rp 1.000.000 untuk piala. Omzet yang didapatkan tergantung pesanan jadi setiap bulan tidak pasti.

Azka Jaya Trhophy selain memproduksi sendiri juga mengambil dari luar yang masih di daerah pasir wetan, sehingga Azka Jaya Throphy hanya menambahkan bagian stiker dan penempelan. Prodak yang terbuat dari logam ini telah menjadi sentra di daerah banyumas terutama di Pasir Wetan yang telah dijadikan Jepannya Banyumas oleh Bapak Nanang selaku ketua paguyuban industri Pasir Wetan dan yang menekuni industri ini. Bapak Nanag memilih bidang usaha ini tentunya karena daerah pasir wetan memiliki potensi yang kaya pada logam, selain itu beliau ditunjuk sebagai ketua paguyuban sehingga selain mengelola usahanya sendiri beliau juga mengurus tatanan industri

pasir wetan dapat berkembang di pasar lokal maupun nasional. Hambatan yang dihadapi dalam prosespersaingan, tentunya dari luar sana yang memiliki usaha yang sama namun menjual harga rendah atau beda tipis. Selain dari itu, prodak- prodak ini belum terdokumentasikan dengan baik sehingga belum bisa memulai kerja sama dengan kedinasan pemerintah karena belum tahu tahap- tahapnya. Ditambah lagi dengan adanya Pandemi Covid 19 jumlah penurunan penjualan sangat banyak karena tidak adanya pemesanan dari mitra karena terkait dengan wisuda online, namun sekarang karenasekolah dan kampus sudah mulai aktif usaha ini sudah mulai berkembang kembali seperti biasanya.

Dari omzet yang sudah didapatkan menjadi salah satu potensi di Desa Pasir Wetan untuk melakukan home industriplakat. Definisi potensi sendiri yaitu kemampuan-kemampuan dan kualitas-kualitas yang dimiliki namun belum dipergunakan secara maksimal. Dengan adanya keberadaan industry rumah tangga di desa mempunyai arti yang penting dalam kerangka pembangunan nasional. Karena keberadaan industri rumah tangga tersebut menjadi solusi bagi tenaga kerja yang belum tertampung dan perbaikan ekonomi masyarakat desa.Industri rumahan pada umumnya memusatkan kegiatan yang biasanya para karyawan berdomisili di tempat yang tidak jauh dari rumah

produksi tersebut.(Anggraini, Susilawati, \& Riani, 2021)

\section{KAJIAN LITERATUR}

Jurnal Griya Cendekia pada tahun 2021 yang berjudul Potensi

Usaha Rumahan di Desa Kali Cinta, Oleh Ade Raras Anggraini, Dewi Susilawati dan Okta Riani dengan hasil penelitian yaitu di Desa Kali Cinta Dusun Talang Batin terdapat potensi usaha rumahan yang berupa perusahaan mikro. Usaha ini dikategorikan usaha mikro dikarenakan dilakukan di rumah sendiri. Perusahaan ini dijalankan oleh keluarga dengan melibatkan pekerja dari keluarga itu sendiri atau tetangga. Usaha rumahan 
yang berkembang di Desa Kali Cinta adalah usaha pembuatan oyek-oyek.

Jurnal JKB pada tahun 2021 yang berjudul Peluang Usaha BisnisRumahan Coklat Rempah oleh Ratna Devi S. dan Edy Legowo dengan hasil penelitian yaitu UKM Soeklat sulit untuk berkembang dan UKM Komasatu beranggotakan petani rempah mempunyai kesulitan untuk memasarkan produk dan kurangnya inovasi produk. Dilakukan

pendampingan pengelolaan usaha, manajemen produksi, pendampingan proses produksi inovasi coklat buah dan pemberian teknologi tepat guna yaitu alat penggiling rempah dan pengemas kedap udara.

Jurnal Pusat Inovasi Masyarakat pada tahun 2021 dengan judul Optimalisasi Potensi Home Industry melalui Digitalisasi Marketing (Kasus: Produksi Emping Rumahan Kampung Pagutan, Desa Sukakerta, Cianjur) oleh Muhammad As'ary, Parhan Mugini, Muhammad Fikri Fakhrurozi, Sugiarti, Garnieta Febrianty Utami dan Dwi Retno Hapsari dengan hasil penelitian yaitu adanya peningkatan pemasaran melalui median daring menjadi peluang besar untuk mengembangkan pasar penjualan emping. Inovasi rasa emping menjadi lebih dinikmati. Optimalisasi

tersebut berupa pelatihan bisnis model canvas, digital marketing dan pengadaan media serta peralatan penunjang usaha tersebut.

\section{METODOLOGI PENELITIAN}

Jenis penelitian yang digunakan adalah metode penelitian deskriptif dengan pendekatan kualitatif. Data diperoleh dari 2 sumber yakni data primer yang didapatkan secara langsung oleh peneliti dari sumber asli (wawancara).Wawancara penulis

lakukan dengan pemilik industritersebut, dengan menyiapkan beberapa daftar pertanyaan. Selain itu apabila responden memberikan pernyataan diluar dugaan maka penulis spontan menambahkan pertanyaan yang terkait. Hal ini bertujuan untuk mengetahui situasi yang akan terjadi sehingga mampu menggali dan menyelidiki lebih dalam. Dan data sekunder yang diperoleh dari peneliti secara tidak langsung melalui media perantara (internet maupun website) maupun dokumen dokumen yang digunakan dalam pengumpulan data, berupa foto- foto ataupun video pendukung yang sesuai dengan tema penelitian(Siyoto \& Sodik, 2015). Analisis data menggunakan metode analisis model interaktif, ada tahapan yang harus dilalui yakni: reduksi data, penyajian data, dan menarik kesimpulan atau verifikasi. Penelitian ini dilakukan pada bulan oktober 2021 di Desa Pasir Wetan dengan objek penelitian pada pelaku bisnis usaha plakat.

\section{HASIL DAN PEMBAHASAN}

Desa Pasir Wetan merupakan pusat industri di Kabupaten Banyumas, segala produk-produk logam, kerajinan logam, alat-alat rumah tangga, alat-alat atau mesin industri yang menggunakan teknologi tepat guna

bisa dihasilkan oleh masyarakat setempat. Desa Pasir Wetan disebut Jepangnya Banyumas. Mayoritas masyarakatnya berprofesi sebagai pedagang, wiraswasta dan buruhindustri. Selain itu karena Desa Pasir Wetan terdapat pasar yang cukup besar dan hampir mayoritas masyarakat menjual baik itu makanan maupun produk kerajinan yang dibuat oleh desa Pasir Wetan antara lain berupa gerabah dan pisau yang dibuat dari besi.Ekonomi yang ada di Desa Pasir Wetan cukup berkembang dan memiliki potensi bahkan dikenal sebagai pedagang karena mayoritas hidup dari kerajinan rumah seperti pengrajin besi, pengrajin emas, pengrajin lencana, dan hasil konfeksi ini di distribusikan sendiri. Namun adanya wabah pandemi Covid- 
19 ini problem ekonomi yang terjadi diantaranya pengangguran, minimnya dan menurunnya jumlah pendapatan bagi pedagang dan pekerjaan tidak tetap.

Desa Pasir Wetan termasuk dalam kecamatan Karanglewas Kabupaten Banyumas, yang memiliki batas-batas administratif sebagai berikut:

- Sebelah Utara : Desa Kebocoran Kec.Kedungbanteng.

- Sebelah Selatan : Desa Pasir KidulKec. Purwokerto Barat.

- Sebelah Timur : Desa

KarangsalamKec.

Kedungbanteng.

- Sebelah barat : Desa Pasir Lor Kec.Karanglewas

Salah satu home industri yang terkenal di desa Pasir Wetan yaitu Azka Jaya Trophy. Beralamatkan di Jl Nur Chaim Rt 01/02 Pasir Wetan, Karanglewas. Usaha ini dimiliki oleh Bapak Nanang Kuntoadi. Dimana Azka Jaya Trophy menyediakan produk seperti trophy/piala, plakat akrilik,

plakat kayu, plakat fiber glass, pin, name tag, medali, samir wisuda dan beberapa produk yang sejenisnya. Usaha ini berdiri pada tahun 2010 dengan jumlah karyawan saat ini sekitar 4-6 orang. Dalam proses produksinya, pemiliki mengatakanmelakukan kegiatan produksibekerja sama dengan beberapa pihak, yang kemudian dalam proses perakitannya dilakukan mandiri oleh karyawan. Produk-produk yang dibuat oleh Azka Jaya Trophy sudah banyak dikenal masyarakat khusus nya masyarakat di wilayah Kabupaten Banyumas. Tidak hanya dikenal secara langsung oleh masyarakat, usaha ini pun eksis di beberapa media sosial. Sering kali membagikan gambar-gambar produk hasil dari Azka Jaya Trophy.Pelanggan banyak berdatangan dari berbagai wilayah, karena kualitas yang diberikan tidak mengecewakan dan selalu mengedepankan kepuasan dari konsumen. Belum lama ini Bapak Nanang menceritakan pengalamannya mendapatkan pesanan untuk perlengkapan wisuda dari Universitas Amikom Purwokerto. Beliau mendapatkan pesanan sebanyak 519 pasang perlengkapan wisuda yang mana selesai dalam waktu kurang lebih 2 minggu. Karena dalam proses produksinya beliau melibatkan beberapa pihak untuk mempercepat penyelesaian pesanan.

Bisnis merupakan suatu pekerjaan yang sangat banyak kita jumpai. Bahkan bisnis adalah suatu peluang usaha yang akan dapat berlangsung bahkan hanya dijalankan oleh satu individu saja. Didalam bisnis orang-orang, terjadi suatu kegiatan penjualan dan juga pembelian antar penjual dan konsumennya, dimana tujuan dari diadakannya bisnis ini tidak lain adalah untuk memperoleh laba

atau yang paling umum didengar adalah untuk memperoleh suatu keuntungan. Namun, hal yang perlu diperhatikan dalam memulai bisnis salah satunya adalah peluang bisnis yang kemudian menjadi acuan dalam melakukan bisnis, yakni dengan mengetahui seminat apa orang dalam bisnis yang akan kita buat, sehingga kedepannya kita dapat mengetahuibisnis ini akan berpeluang atau tidak jika terus dijalankan, karena jangan sampai bisnis yang diusahakan hanya memperoleh kerugian,

Suatu bisnis bisa saja berbentuk hal-hal yang berbau seni dalam pengerjaannya, contohnya yang paling sering kita temukan saat ini adalah mengenai desain. Perkembangan teknologi membuat para desain grafis menjadi lebih praktis dalam melakukan aktivitasnya. Bisnis desain ini sendiri merupakan suatu perpaduan antara bisnis dan juga desain. Banyak akhirnya orang-orang yang memilih untuk mencoba langsung terjun ke dalam dunia bisnis desain ini melihat kebutuhan konsumen pula, sesuai dengan perkembangan teknologi dimasa sekarang(Asri, 2020). Contoh yaitu 
dibidang plakat, banyak akhirnya orangorang membutuhkan jasa pembuatan plakat dari suatu event- event atau menjadikannya hadiah untuk sahabat, atau orang-orang terkasihnya.

Potensi dalam pasar karya desain memiliki kecenderungan terus berkembang(Ayuni \& Kurniawan, 2020). Hal ini merupakan suatu informasi yang berguna terutama bagi orang-orang yang ini memulai bisnisnya di dalam desain. Plakat itu sendiri merupakan suatu bentuk karya desain yang kemudian banyak diminati banyak konsumen pasar. Dimana para konsumen dalam suatu daerah anyak membutuhkan jasa para pembuatplakat untuk kepentingan perusahaan bahkan juga digunakan dalam kepentingan pribadi orang-orang. Usaha plakat disini dinilai sebagai bentuk usaha dengan mengedepankansisi kreatif para pekerja usahanya yang dengan cara bersaing pula dan meningkatkan secara maksimal hasil untuk menarik para konsumen atau penggunanya.

Untuk proses pemesanan dan distribusi, pembeli kebanyakan mendatangi lokasi secara langsung untuk memesan produk sesuai dengan yang di inginkannya namun ada juga yang melakukan pemesanan secara online dengan memberikan contoh desain produk yang di inginkan. Untuk pemesanan produk dengan jumlah yang sedikit hanya perlu memerlukan beberapa waktu untuk proses produksi sehingga pembeli dapat langsung membawa pulang pesanan dihari yang sama pada waktu pemesanan. Berbeda dengan pemesanan produk yang banyak perlu waktu yang lebih lama sampai beberapa hari untuk proses kegiatan produksi.

$$
\text { Kegiatan promosi }
$$

produk/informasi mengenai produkproduk yang di buat dilakukan Azka Jaya Trophy memanfaatkan platform media sosial dan web. Secara mudah konsumen dapat mengakses informasi penting mengenai industri Azka jaya Trophy.

\section{PENUTUP}

$\begin{array}{lr}\text { Industrialisasi } & \text { sebagai } \\ \text { pembangunan ekonomi ralui } & \text { melalui } \\ \text { transformasi sumber daya dan aktivitas } \\ \text { energi yang digunakan sebagai upaya } \\ \text { melipat gandakan produk, dan }\end{array}$
keberadaan home industri memiliki arti penting dalam kerangka pembangunan nasional. Penelitian yang disusun menggunakan metode penelitian deskriptif dengan pendekatan kualitatif. Dengan hasil kesimpulan penelitian diperoleh bahwa desa Pasir Wetan merupakan pusat industri di Kabupaten Banyumas, segala produk-produk logam, kerajinan logam, alat-alat rumah tangga, alat-alat mesin industri yang menggunakan teknologi tepat guna bisa dihasilkan oleh masyarakat setempat. Salah satu home industri yang terkenal di desa Pasir Wetan yaitu Azka Jaya Trophy. Dimana industri ini memproduksi plakat/piala, pin, plakat akrilik, plakat kayu, plakat fiber glass, pin, name tag, medali, samir wisuda dan beberapa produk yang sejenisnya. Plakat itu sendiri merupakan suatu bentuk karya desain yang kemudian banyak diminati banyak konsumen pasar. Dimana para konsumen dalam suatu daerah banyak membutuhkan jasa para pembuat plakat untuk kepentingan perusahaan bahkan juga digunakan dalam kepentingan pribadi orang-orang. Yang mana dalam proses produksinya pengrajin melibatkan beberapa pihak untuk bekerja sama menghasilkan produk-produk dari logam. Dengan mengedepankan kualitas produk yang dihasilkan tentu akan memberikan kepuasan yang baik dari para konsumen/pelanggan.

Dalam meningkatkan potensi yang ada, maka pelaku usaha perlu adanya peningkatan terkait produk, pelayanan, sarana prasarana toko guna menunjang kenyamanan konsumen sehingga loyalitas konsumen dapat dipertahankan. 
Perlunya inovasi digital marketing hal ini mengingat potensi bisnis yang tinggi di media sosial dan halini tidak lepas dari adanya persaingan bisnis yang sangat keras. Diperlukannya perhatian lebih oleh pelaku bisnis terkait SDM pendukung, hal ini bisa dilakukan dengan kerja sama atau kolaborasi dengan personal yang ahli dibidangnya guna menarik target marketing di sosial media serta mampubersaing.

\section{DAFTAR PUSTAKA}

Anggraini, A. R., Susilawati, D., \& Riani, O. (2021). Potensi Usaha Rumahan di Desa Kali Cinta. Jurnal Griya Cendikia, 70.

Asri, D. P. (2020). Perlindungan Hukum Hak Kekayaan Inteletual Bagi Produk Kretif Usaha Kecil Menengah Di Yogyakarta. Jurnal Hukum Ius Quia Iustum Faculty of Law, 133145.

Ayuni, D. R., \& Kurniawan, M. Y. (2020). Pelatihan Desain Kretif Marketpale Dan Media Sosial Bagi Pengrajin Batu Permata Khas Banjar Martapura Dalam Menarik Minat Pembeli. Jurnal Pengabdian Al-Ikhlas, 144-150.

Siyoto, S., \& Sodik, M. A. (2015). Dasar Metodologi Penelitian. Sleman: Literasi Media Publising. 